\title{
Modified Rice Straw Enhanced Cadmium (II) Immobilization in Soil and Promoted the Degradation of Phenanthrene in Co-Contaminated Soil
}

\author{
Ali Mohamed Elyamine ${ }^{1,2,3}\left(\mathbb{D}\right.$, Mohamed G Moussa ${ }^{1,2,4} \oplus$, Javaria Afzal ${ }^{1,2}(\mathbb{C}$, \\ Muhammad Shoaib Rana ${ }^{1,2}$, Muhammad Imran ${ }^{1,2}$, Xiaohu Zhao ${ }^{1,2}$ and Cheng Xiao $\mathrm{Hu}{ }^{1,2, *}$ \\ 1 Key Laboratory of Arable Land Conservation (Middle and Lower Reaches of Yangtze River), \\ Ministry of Agriculture, Research Center of Micro-elements, College of Resource and Environment, \\ Huazhong Agricultural University, Wuhan 430070, China; elyoh@hotmail.fr (A.M.E.); \\ MohamedGomaa_Ali@agr.asu.edu.eg (M.G.M.); juvaria_afzal@outlook.com (J.A.); \\ muhammadshoaib@webmail.hzau.edu.cn (M.S.R.); imrangorayauaf@yahoo.com (M.I.); \\ xhzhao@mail.hzau.edu.cn (X.Z.) \\ 2 Hubei Provincial Engineering Laboratory for New Fertilizers, Huazhong Agricultural University, \\ Wuhan 430070, China \\ 3 Faculty of Science and Technology, Department of Life Science, University of Comoros, Moroni 269, Comoros \\ 4 Soil and Water Research Department, Nuclear Research Center, Egyptian Atomic Energy Authority, \\ Abou Zaabl 13759, Egypt \\ * Correspondence: hucx@mail.hzau.edu.cn
}

Received: 6 March 2019; Accepted: 27 April 2019; Published: 3 May 2019

\begin{abstract}
Very limited information is available about heavy metal-polycyclic aromatic hydrocarbons (PAHs) depollution involving the modified natural material in soil. Using phenanthrene and cadmium (Cd) as model, this study investigated the effect(s) of modified rice straw by a $\mathrm{NaOH}$ solution and on PAHs, heavy metal availability, and their interactions. Treatment included chemical contaminant with/without modified/unmodified rice straw. Fourier Transform Infrared (FTIR) analysis revealed that certain functional groups including anionic matters groups, which can a complex with $\mathrm{Cd}^{2+}$, were exposed on the modified rice straw surfaces. Therefore, $\mathrm{Cd}$ concentration was significantly reduced by about $60 \%, 57 \%, 62.5 \%$, and, $64 \%$ in the root, shoot, $\mathrm{CaCl}_{2}$, diethylenetriaminepentaacetic acid (DTPA), and extractable Cd, respectively. Subsequently, the prediction of the functional profile of the soil metagenome using Clusters Orthologous Groups (COGs) and the Kyoto Encyclopedia of Genes and Genomes (KEGG) database revealed that the significantly changed individual COGs belonged to the carbohydrate metabolism, ion transports, and signaling (including cytochrome P450s) categories. This indicated that ion transports might be involved in $\mathrm{Cd}$ management, while carbohydrate metabolism, including bisphenol, benzoate, ethylbenzene degradation, and cytochrome P450s, were rather involved in phenanthrene metabolism. The exposed functional group might serve as an external substrate, and P450s might serve as a catalyst to activate and initiate phenanthrene metabolism process. These finding offer confirmation that modified straw could promote the reduction of heavy metal and the degradation of PAHs in soil.
\end{abstract}

Keywords: alkali modified straw; bio-absorbent; phenanthrene metabolism; bio-immobilization; bioavailability; enzyme-chemical interaction 


\section{Introduction}

Since the industrial revolution, the contamination of agricultural soils with heavy metals and polycyclic aromatic hydrocarbons (PAHs) has increasingly become a serious global environmental concern and poses a huge threat to human beings and natural ecosystems. Cadmium $(\mathrm{Cd})$ is one of the most known toxic pollutants in toxicological research [1]. Phenanthrene is the simplest aromatic hydrocarbon with three-fused ring compound [2] and contains both "bay-region and K-region epoxides" which are highly reactive both chemically and biologically [3]. Both chemicals negatively affect not just plant physiology and biology [4-6] and soil microorganisms $[7,8]$, they also pose health risks for both humans and animals [6] through food-chain bioaccumulation [9].

Diverse approaches such as chemical precipitation, thermal processes, and physical separation, have been developed and made available to clean up the contaminated environment. However, these techniques not only present several disadvantages, such as the destruction of particle structure and microbial activities in soils, as well as high cost [10-12], they also, in many cases, transfer the pollutant from one form to another. Phytoremediation, which uses metal hyperaccumulator plants to remove contaminants from soils, is another cost-efficient and environmentally friendly remediation technology; however it has faced some challenges as well $[13,14]$, such us the requirement of full understanding about how the pollutant is managed within plants at both physiological and genetic levels [15].

Microbial degradation is the major technique mostly used to remove, alter, or isolate PAH [16]. Microbes are well-known for their ability to catabolize and breakdown the organic compound into less complex metabolites [16] or into inorganic minerals such as $\mathrm{H}_{2} \mathrm{O}$ and $\mathrm{CO}_{2}$ (under aerobic conditions) [17] or $\mathrm{CH}_{4}$ (under anaerobic conditions) [3]. Therefore, a significant number of phenanthrene-degrading bacteria and fungi have been identified and isolated. However, based on the mechanism by which most of larger molecular weight PAHs such as phenanthrene are degraded, this process requires the addition of external substrates such as bicarbonate molecules to activate their metabolism $[17,18]$ or the hydrogenation of the aromatic ring (anaerobic metabolism) [3]. In addition, considering the fact that the inoculants of exogenous/endogenous microorganisms must be able to overwhelm biotic and abiotic stress in the environment, the use of a free microorganism for bioremediation of contaminated sites in a large scale can fail.

Many studies have thoroughly invested the interactions between PAHs and heavy metals, their individual effects on the soil organisms and plants toxicity, and different methods for the control and management their respective effects $[19,20]$. Though $\mathrm{Cd}$ is everlasting, its availability $\left(\mathrm{Cd}^{2+}\right)$ may decrease in the environment by (1) a chelating process via chemical or physical remediation or (2) by shifting their valence by redox reaction by interacting in some specific cases with PAHs [20]. However, to the best of our knowledge, this alternative is less exploited for the purpose of PAHs-heavy metal environmental depollution, and no information is available about their depollution involving the modified natural material, such as straw, in soil.

Thus, natural materials that are available in large quantity, such as rice straw, may have potential as inexpensive sorbents or immobilizers for both organic and inorganic pollutants. As a heterogeneous material, rice straw has been used as a biosorber to reduce heavy metals in aquatic environments [21] and as a chelator source of inorganic pollutants in soil [22,23]. Agricultural crop residues, besides from the basic constituents, usually contain extractives and diverse molecules composed of a variety of functional groups capable of binding heavy metal [24]. The metals cations have a good affinity with the anionic matters present on the rice straw surfaces and can form stable complexes [25]. Subsequently, the use of organic fertilizers was shown to have positive effects on the removal of PAH in the soil [26]. Indeed, there is a close correlation between soil microbial community and the degradation of pollutants [27]. In addition, the micro-fauna densities attached to plant residues have increased with the decomposition of organic matter through the mineralization and the humification effect of microorganisms [28,29].

In the present study, phenanthrene and $\mathrm{Cd}$ were used as models of organic and inorganic pollutants to investigate the effect(s) of modified rice straw on PAHs and heavy metal availability, as well as their 
interaction. Rice straw was treated with a $\mathrm{NaOH}$ solution to produce carbonaceous molecules for the PAHs' degradation activation and to provide more binding sites for $\mathrm{Cd}^{2+}$. This paper aims to examine the effect of this modified material on (1) $\mathrm{Cd}$ and phenanthrene availability; (2) microbial functional profile prediction; and (3) phenanthrene degradation.

\section{Results}

\subsection{Characterization of Rice Straw by FTIR}

To understand the change sequence of the functional groups of treated and not-treated rice straw, FTIR analysis was performed in the fingerprint region of the absorbance spectra (Figure 1). The characteristics absorption bands and different functional group corresponded to different peaks in Figure 1 are listed in the Table 1. According to previous literature [22,24], the bands at approximately $1640-1500 \mathrm{~cm}^{-1}$ correspond to either the acetyl or uranic ester groups of the hemicelluloses or the ester linkage of carboxylic group of the ferulic and p-coumaric acids of lignin and/or hemicelluloses. The bands at 1450 and 1407 $\mathrm{cm}^{-1}$ represent the aromatic skeletal stretching vibration $\mathrm{C}=\mathrm{C}$ of lignin. On the other hand, the bands at $1242-1162 \mathrm{~cm}^{-1}$ can be ascribed to the C-O-C stretching vibration in aryl-alkyl ether, the C-O-C asymmetric stretch vibration, or $\mathrm{C}-\mathrm{O}$ stretching and $\mathrm{C}-\mathrm{O}$ deformation in cellulose and hemicellulose. The band at approximately $1321 \mathrm{~cm}^{-1}$ has been attributed to the CO- symmetric stretching of deprotonated ester, and the band at and $1302 \mathrm{~cm}^{-1}$ has been ascribed to the $\mathrm{OH}$ deformation of phenolic $\mathrm{OH}$. All cross-peaks were positive, implying that signals of functional groups activated by $\mathrm{NaOH}$ had simultaneous intensity changes with each other in the same direction. The bands at 2919 and $2853 \mathrm{~cm}^{-1}$ were ascribed tp the $\mathrm{C}-\mathrm{H}$ stretching vibration of aliphatic compounds. Though the characteristic peaks of both spectra SNT (straw not treated) and ST (treated straw) present a very similar profile from $1268-3440 \mathrm{~cm}^{-1}$, there were frequency shifts (intensity changes) between both rice straw samples. As shown in the Figure 1, the highest change in intensity was observed after $1268 \mathrm{~cm}^{-1}$. The absorptions at $1268-1039 \mathrm{~cm}^{-1}$ attributed to the silica (Si-O bending and Si-O stretching) decreased considerably. This indicated that a portion of silica was removed after the treatment of rice straw. The changed profile of the absorption at $1039-400 \mathrm{~cm}^{-1}$ for ST could suggest that after chemical treatment and the removal of silica, the groups $\mathrm{C}-\mathrm{O}, \mathrm{C}-\mathrm{O}-\mathrm{H}, \mathrm{C}-\mathrm{H}$, and $\mathrm{O}-\mathrm{H}$ became more exposed in the material.

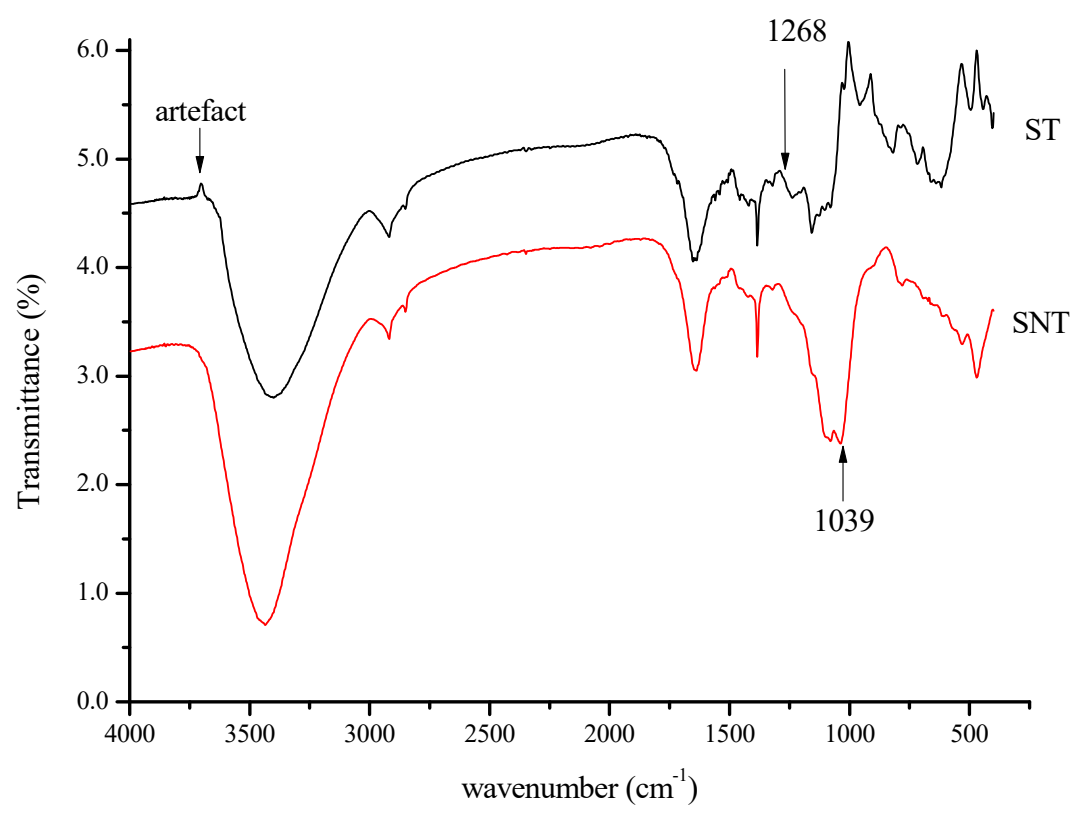

Figure 1. FT-IR in $4000-400 \mathrm{~cm}^{-1}$ spectra region of rice straw. SNT (straw not treated) indicates the spectra of rice straw untreated (natural), and ST (treated straw) indicates the spectra of rice straw treated with $\mathrm{NaOH}$. 
Table 1. Typical absorption bands and the main functional groups of rice straw.

\begin{tabular}{|c|c|c|}
\hline Wave Number $\left(\mathrm{cm}^{-1}\right)$ & Functional Groups & Compounds \\
\hline 3430 & O-H stretching & cellulose and lignin \\
\hline 2919 and 2853 & C-H stretching vibration & Aliphatic compounds \\
\hline $1640-1500$ & $\mathrm{C}=\mathrm{O}$ & Ketone, carbonyl group \\
\hline 1450-1407 & $\mathrm{C}=\mathrm{C}$ stretching vibration & Aromatic skeletal \\
\hline 1388 & $\mathrm{C}-\mathrm{H}$ blending vibration & alkanes \\
\hline 1321-1302 & $\mathrm{C}-\mathrm{O}$ stretching and $\mathrm{O}-\mathrm{H}$ blending & phenols, alcohols and esters \\
\hline $1268-1039$ & Si-O bending & \\
\hline $1242-1162$ & $\mathrm{C}-\mathrm{O}-\mathrm{C}$ stretching & aryl-alkyl ether \\
\hline 1070 & $\begin{array}{l}\mathrm{C}-\mathrm{O}-\mathrm{C} \text { stretching vibration or } \mathrm{C}-\mathrm{O} \\
\text { stretching and } \mathrm{C}-\mathrm{O} \text { deformation }\end{array}$ & ethanol group \\
\hline 1009 & $\mathrm{C}-\mathrm{O}-\mathrm{H}$ and $\mathrm{O}-\mathrm{H}$ blending & $\begin{array}{c}\text { Decomposition of hemicellulose and } \\
\text { cellulose }\end{array}$ \\
\hline $900-700$ & $\mathrm{C}-\mathrm{H}$ & Aromatic hydrogen \\
\hline $700-400$ & C-C stretching & \\
\hline
\end{tabular}

\section{2. $C d$ and Phenanthrene Determination}

\section{Cd Determination in Plant}

The mean concentrations of $\mathrm{Cd}$ in the plant root and shoot in different treatments were investigated and are plotted in Figure 2. In the treatment with $\mathrm{Cd}$ only, although the application of rice straw significantly decreased $\mathrm{Cd}$ concentration in the root (Figure 2A) and shoot (Figure 2B) compared to $\mathrm{Cd}$ alone, the reduction was particularly marked in the modified rice straw inoculated treatment $(p<0.01)$. The comparison of $\mathrm{Cd}$ concentration in plant tissues with the available $\mathrm{Cd}$ concentration $\left(\mathrm{Cd}^{2+}\right)$ in different soil treatments was found to have a positive correlation. However, $\mathrm{Cd}$ accumulation (plant dry weight $\times \mathrm{Cd}$ concentration) was found to decrease in the root by about $43 \%$ and $55 \%$, respectively, in Cd applied to non-treated straw (CdSNT) and to treated straw (CdST), compared to $\mathrm{Cd}$ alone. Further, in the presence of phenanthrene (PCd) treatment, $\mathrm{Cd}$ concentration uptake by the plant was significantly reduced by about $41 \%, p=0.027$, compared to the treatment with $\mathrm{Cd}$ alone. $\mathrm{Cd}$ accumulation recorded in the root was reduced by about $53 \%, p=0.0024$, and $65 \%, p=0.0018$, in the unmodified (PCdNST) and modified (PCdST), respectively. Cd concentration in the shoot was significantly decreased by $38 \%$ and $52 \%$ in CdSNT and CdST, respectively, compared to Cd alone treatment (Figure 2B). However, in PCd treatment, the reduction was by about $43 \%$ compared to $\mathrm{Cd}$ treatment alone. Furthermore, $58 \%$ and $62 \%$ of $\mathrm{Cd}$ concentration was reduced, respectively, in PCdSNT and PCdST, compared to $\mathrm{Cd}$ alone. Considering the total $\mathrm{Cd}$ accumulated in the root and shoot, the sequence of $\mathrm{Cd}$ accumulation follows this trend: $\mathrm{Cd}$ alone $>\mathrm{PCd}>\mathrm{CdSNT}>\mathrm{Cd}$ ST $>$ PCdNST $>$ PCdST, with $1.708,1,0.98,0.78,0.77$, and $0.588 \mathrm{mg} \mathrm{Cd} \mathrm{kg}^{-1} \mathrm{DW}$, respectively. This result highlights the fact that the modified rice straw inoculation significantly decreases the total $\mathrm{Cd}$ reaching the plant; however, the amount of $\mathrm{Cd}$ accumulated in the presence of phenanthrene was much more reduced as compared to that of $\mathrm{Cd}$ alone 


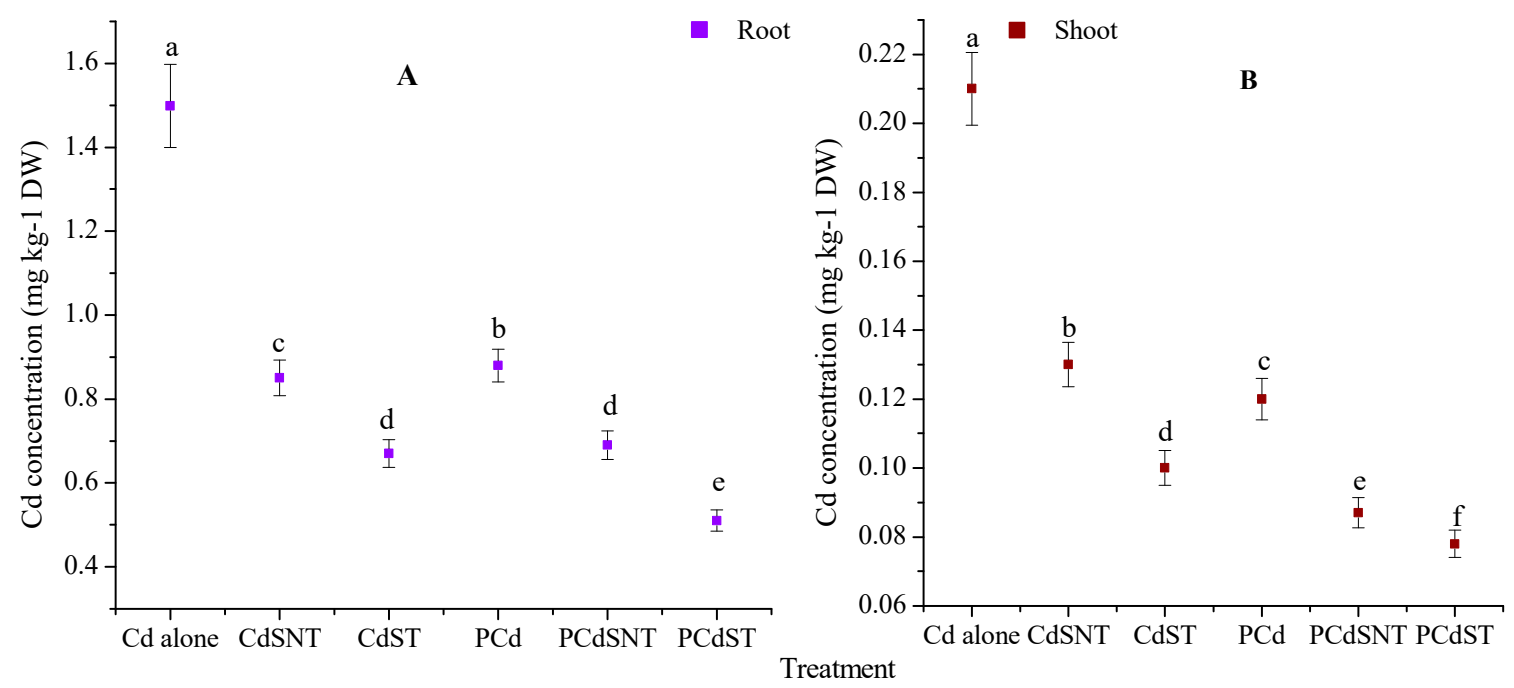

Figure 2. Effect of modified and unmodified rice straw on Cd concentration in the root (A) and shoot (B). In each group (A and $\mathbf{B})$, the lowercase letters indicate a significant difference within different treatments (Tukey'tests, $p<0.001$ ).

\subsection{Cd Extraction in Soil}

\subsection{1. $\mathrm{CaCl}_{2}$ Extractable Cd}

Rice straw application significantly $(p<0.05)$ reduced $\mathrm{Cd}$ concentration in the $\mathrm{CaCl}_{2}$-extractation soil fraction compared to the control (Figure 3A). In the treatment with $\mathrm{Cd}$ only, the concentrations of $\mathrm{Cd}$ in pore water were significantly lower when rice straw was applied as a modified material contrary to CdSNT. Furthermore, in the presence of phenanthrene, the $\mathrm{Cd}$ concentration of the $\mathrm{CaCl}_{2}$-extractable was 0.6-fold reduced, compared to $\mathrm{Cd}$ alone. Though rice straw application was more effective in reducing the pore water $\mathrm{Cd}^{2+}$ concentration, the modified material was found to be the most effective. The treatment with unmodified material reduced pore water $\mathrm{Cd}^{2+}$ concentration by $41 \%$ and $59 \%$, respectively, in CdSNT and PCdSNT, while the reduction observed in the modified material (CdST) and (PCdST) treatment was $55 \%$ and $66 \%$, respectively.

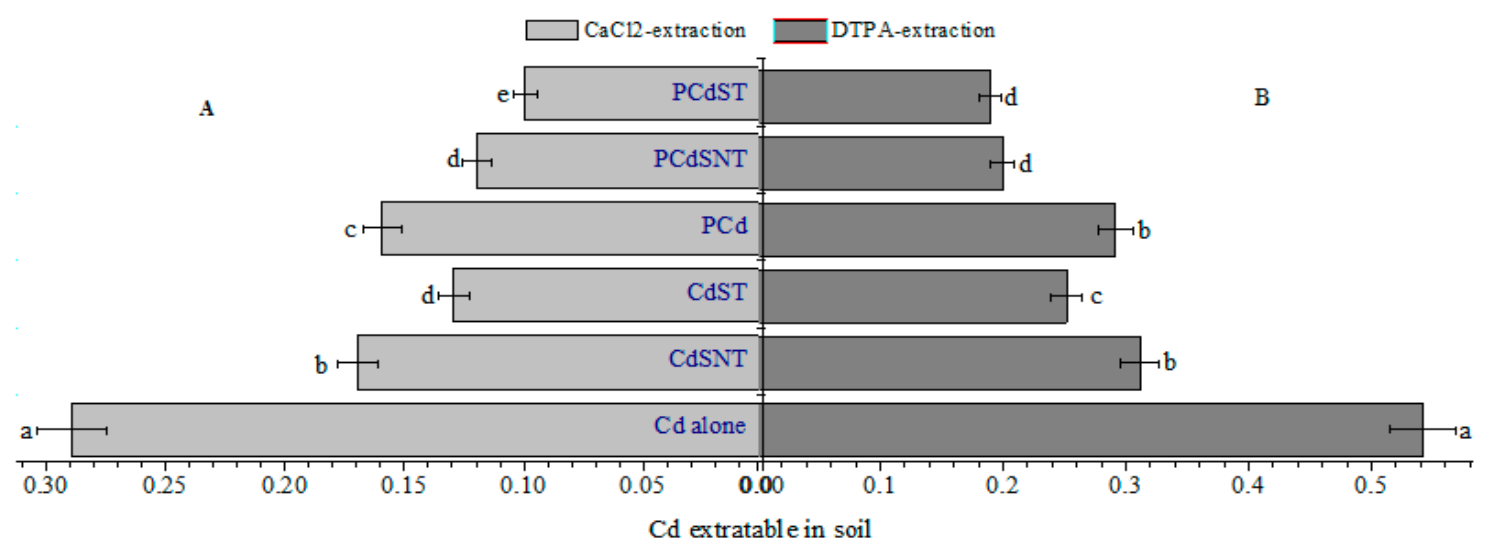

Figure 3. Effect of modified and unmodified rice straw on $\mathrm{Cd}$ extraction by $\mathrm{CaCl}_{2}(\mathbf{A})$ and diethylenetriaminepentaacetic acid (DTPA) (B) in soil. In each group (A and B), the lowercase letters indicate a significant difference within different treatments (Tukey'tests, $p<0.001$ ).

\subsubsection{Diethylenetriaminepentaaacetic Acid (DTPA)-Extractable Cd}

Plant-available $\mathrm{Cd}$ significantly decreased with the addition of rice straw, and the effect was more pronounced in the modified materials - either in single Cd treatment (CdST) or in the mixture treatment (PCdST) (Figure 3B). The concentration of plant-available Cd in single Cd treatment was 
more reduced $(p<0.01)$ in the modified rice straw application as compared to the unmodified one. In the mixture treatment, despite the observed reduction in the diethylenetriaminepentaacetic acid (DTPA)-extractable Cd, no significant difference was noted between the PCdST and PCdSNT treatments. However, the application of unmodified straw reduced plant-available Cd concentration by $43 \%$ and $63 \%$, respectively, in CdSNT and PCdSNT, while the reduction observed in the modified material treatment was about $54 \%$ and $65 \%$, respectively.

\subsection{Phenanthrene Concentration in Soil}

In the single phenanthrene treatment, the initial concentration of phenanthrene applied in soil was significantly reduced $(p<0.001)$ by $94 \%$ in the phenanthrene treatment applied with treated rice straw (PST) as compared to non-treated straw (PSNT), which recorded only $76 \%$ in reduction (Figure $4 \mathrm{~A}$ ). In the mixture treatment, the phenanthrene concentration in phenanthrene and $\mathrm{Cd}$ treatment applied with treated rice straw (PCdST) and non-treated straw (PCdNST) was more significantly reduced by $96 \%$ and $82 \%$, respectively, compared to the control. This result suggests that chemical treatment could accelerate the removal of phenanthrene in soil.

Therefore, to better assess the impact of modified rice straw on degradation of phenanthrene in soil, soil samples contaminated with phenanthrene were only collected weekly to determine the contaminant concentration. The result showed that, within a week of incubation, $10 \%$ of phenanthrene applied in soil was reduced in PST, compared to 5\% observed in PNST (Figure 4B). After 120 days, $97 \%$ of phenanthrene concentration was removed in PST compared to $88 \%$ and $77 \%$ recorded in PNST and the control treatment, respectively. This suggested that the modified rice straw might somehow be involved in phenanthrene removal in soil.

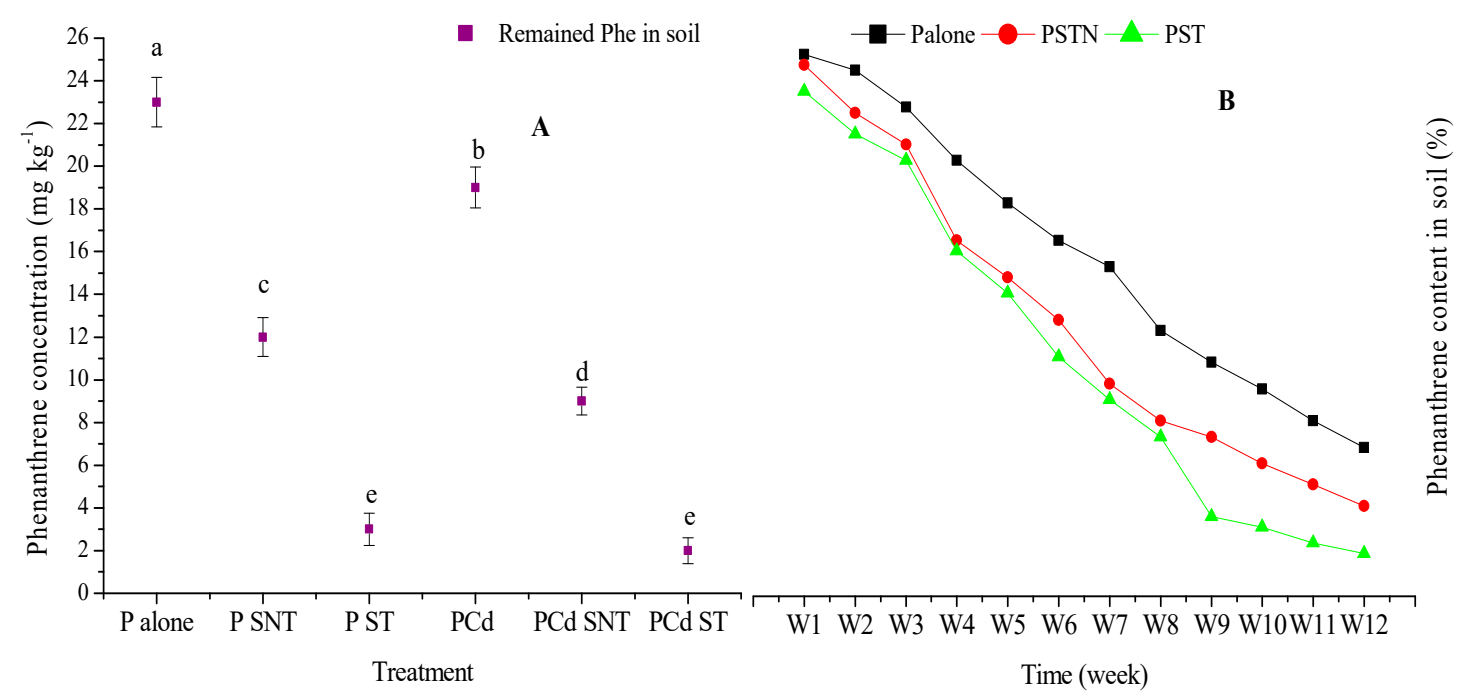

Figure 4. Effect of modified and unmodified rice straw on phenanthrene concentration in soil after 120 exposure days (A) and in each week during the 120 experimental days (B). Results present the mean of three replicates compared by Tukey's tests. The lowercase letters indicate a significant difference within different treatments at $p<0.01$ and $p<0.05$ in A and B, respectively.

\subsection{Predicted Functional Profile of Soil Metagenomes}

The presence of possible metabolites or others function involved in the metabolism and sorption of both organic and inorganic pollutants could highlight the reduction of pollutant availability and/or their total concentration in soil. Thus, a quantitative comparison of Clusters Orthologous Groups (COGs) among treatments soil samples was performed to identify functions among the treatment (Figure 5A). It was revealed that almost all the significantly changed individual COGs belonging to the categories of carbohydrate metabolism, ion transport, and energy metabolism were enriched in all treatments. In the single phenanthrene treatment, genes involved in carbohydrate metabolism were 
enriched remarkably compared to the control. However, the application of modified or unmodified straw did not manifest any significance difference regarding to functional diversity, with a similar Shannon index of 6.12 and 6.45, respectively. In the mixture treatment, the ion transport and $A B C$ transporter involved in xenobiotic organic were significantly enriched in all treatments, but the trend was more pronounced $(p<0.01)$ in the treatment applied with rice straw either modified or unmodified.

One other COG category enriched in phenanthrene treatment was molecular signaling. However, because the results gained for the COG categories disclosed a lack of congruency among the treatments, metagenomic sequences were allocated to the Kyoto Encyclopedia of Genes and Genomes (KEGG) database, which is particularly suitable for a comparison of metabolic pathways (Figure 5B). The comparison revealed that cytochrome P450, the metabolism of xenobiotic by cytochrome P450, and the drug metabolism cytochrome P450 were the most significant dominants in abundance. All of these genes were more enriched in the single phenanthrene treatment compared to the mixture treatment. This suggests that cytochrome P450 was involved in the degradation of phenanthrene.
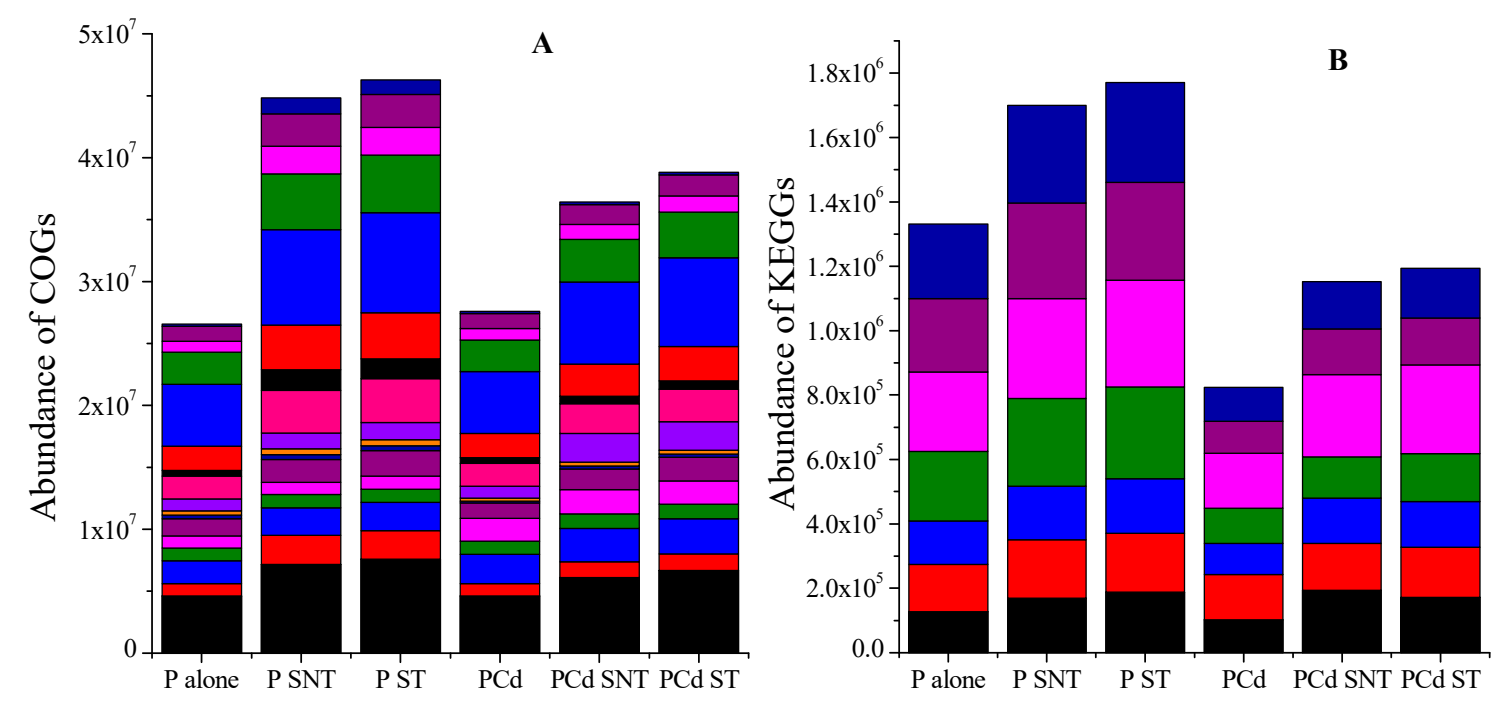

Treatment
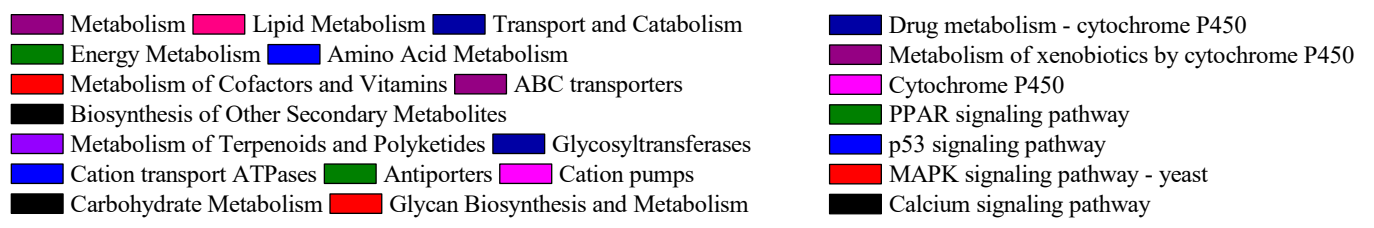

Figure 5. Effect of modified and unmodified rice straw on the distribution of Clusters Orthologous Groups (COGs) functional categories (A) and KEGGS metagenome functional prediction of the dataset (identified OTUs) (B).

\subsection{Organic Products Involved in the Degradation Process}

Figure 6 shows, in percentages, the different genes involved in the metabolism of organics materials identified in the different soil samples. Though the profiles of different treatments were similar, the abundance of genes involved in the phenanthrene single treatment was more pronounced in comparison with that in the mixture treatment. Genes involved in phtalic and salicylic acid metabolism, bisphenol, benzoate, and ethylbenzene degradation were more enriched in both treatments. This suggests that the enrichment of nearly all of genes involved in the degradation of different molecules in the single and mixture treatments with phenanthrene are linked to the degradation/transformation of phenanthrene. 


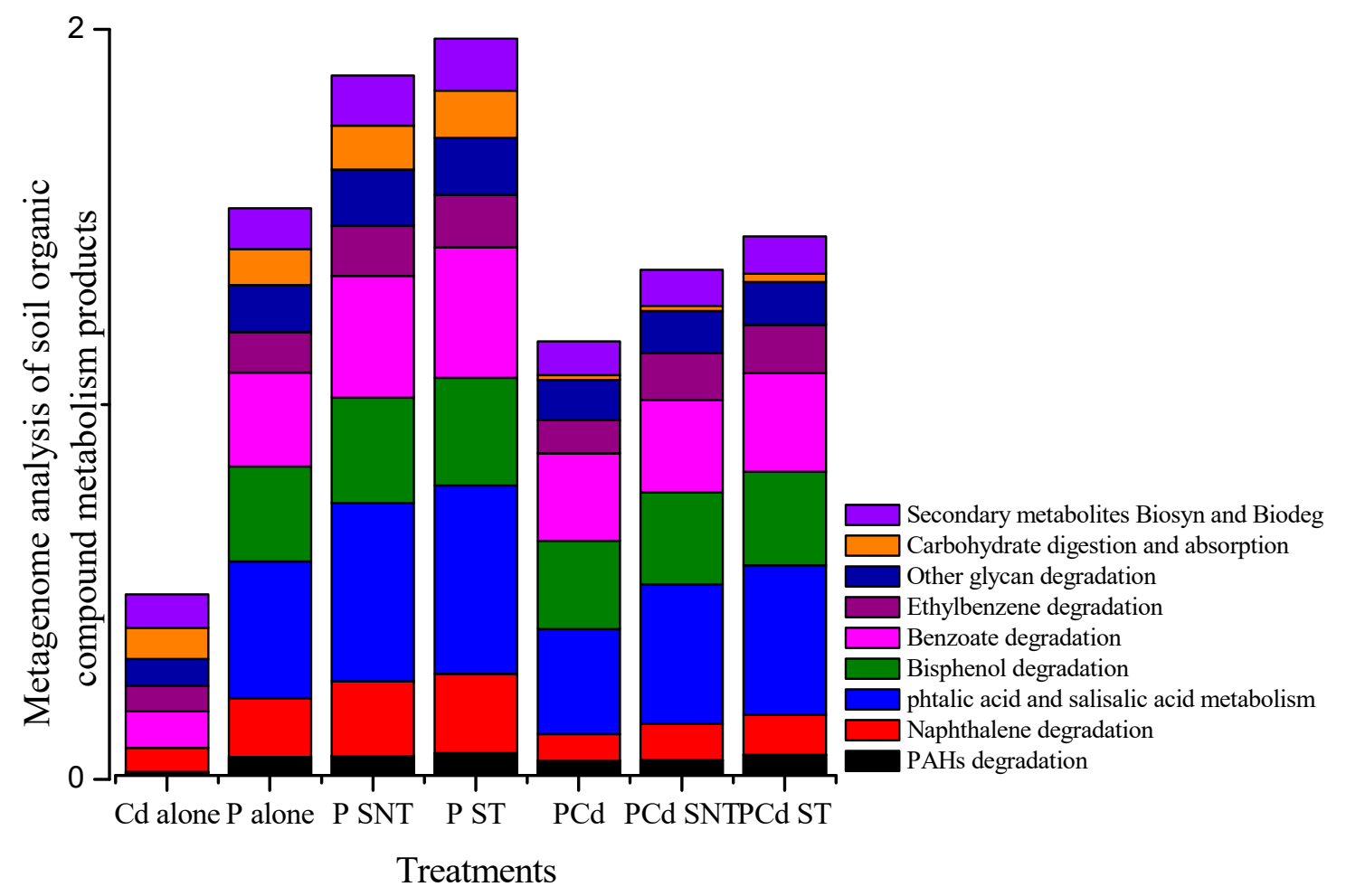

Figure 6. Effect of modified and unmodified rice straw on different genes involved in the metabolism of organics materials identified in the different soil samples (in percentage).

\section{Discussion}

\subsection{Rice Straw Structure}

Agricultural crop residues, besides from the basic constituents, usually contained extractives, and several molecules composed by a variety of functional groups capable of binding heavy metal [24]. Studies have reported the use of $\mathrm{NaOH}$ to modify crop materials and improve metal sorption ability [30]. This could explain the profile variation and the frequency shifts between both rice straw samples (Figure 1). Additionally, a portion of silica was removed after the treatment of rice straw, leading to a significant variation of ST profile at $1039-400 \mathrm{~cm}^{-1}$. This suggests that after the removal of silica, some functional groups such as $\mathrm{C}-\mathrm{O}, \mathrm{C}-\mathrm{O}-\mathrm{H}, \mathrm{C}-\mathrm{H}$, and $\mathrm{O}-\mathrm{H}$ might became more exposed in the material. This is similar with the result found by Rocha et al., which reported that after alkali treatment the superficial layer of protective silica and the natural resins present in the rice straw were largely removed [21]. Li et al. showed that $\mathrm{NaOH}$ increased the $\mathrm{O}$ content, increased the surface basicity [31], and condensed organic matter to facilitate the subsequent activation of the materials [32]. Similarly, the evolution of pyrolysis product including $\mathrm{C}-\mathrm{H}, \mathrm{C}-\mathrm{O}-\mathrm{H}$, and $\mathrm{C}-\mathrm{O}-\mathrm{C}$ functional groups were enhanced though chemical treatment; particularly, $\mathrm{C}=\mathrm{O}$ was increased through $\mathrm{NaOH}$ treatment [33].

\subsection{Rice Straw Decreased Cd Content in Sunflower Root and Shoot}

The mobility and bioavailability of heavy metals are controlled by several factors and processes, including soil $\mathrm{pH}$, soil organic matter content, metal form, adsorption, and the desorption process. Among them, soil $\mathrm{pH}$ plays a considerable role in the speciation and mobility of heavy metals, since its variation negatively correlates with metal availability and changes its impact on soil microorganisms and plants [23]. Indeed, at a low $\mathrm{pH}$, organic and mineral soil materials tend to complex with metal to form stable metal-organo-mineral complexes. Conversely, when the $\mathrm{pH}$ is at a high level, this complex dissociates and ultimately increases the availability of the metal in the surrounding environment [23]. Thus, because of the addition of rice straw increased soil pH (Table 2), we can suppose that organic 
and mineral materials in the soil will associate with $\mathrm{Cd}^{2+}$ and form complexes in soil. Organic matter content is another key factor that can affect the bioavailability of $\mathrm{Cd}$. Organic matter, in its dissolved form, can serve as a metals chelate and increase its mobility and uptake to plants; in its compact form, it constitute a major factor contributing to the soil ability to retaining metals in a non-exchangeable form [34]. The decomposition of rice straw and the chemical treatment led to the increase and exposure of certain functional groups, which can form complexes with $\mathrm{Cd}^{2+}$ (Figure 1). The metals cations have a good affinity with the anionic matters, such as $\mathrm{COO}^{-}$and the phenolic group present on the rice straw surfaces, and can form stable complexes [25]. Park et al. showed that the sorption of $\mathrm{Pb}^{2+}$ in peanut straw was generally facilitated through complexation with the surface functional groups, especially carboxylic groups $(\mathrm{COOH})$ [35]. This could explain why overall $\mathrm{Cd}$ content in plants was significantly reduced after rice straw addition (Figure 2). Therefore, if $\mathrm{Pb}^{2+}$ can be sorbed by $\mathrm{COOH}$, other divalent metal cations such as $\mathrm{Cd}^{2+}$ could also react with the same groups in order to form stable complexes according to the following Figure 7.

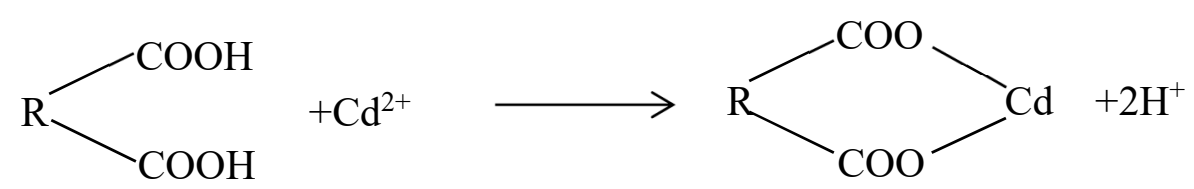

Figure 7. Sorbtion mechanism by which some functional group such as $\mathrm{COOH}$ complex with $\mathrm{Cd} 2+$ to immobilize it in soil.

Table 2. Influences of modified and unmodified rice straw on soil physical and chemical properties.

\begin{tabular}{llllll}
\hline Treatment & CEC & $\mathbf{p H}$ & SOM & Total P & Available P \\
\hline Cd alone & 12.13 & 6.8 & 17.59 & 15.70 & 1.90 \\
CdSNT & 15.72 & 6.5 & $64.05^{* *}$ & 19.05 & $6.22 *$ \\
CdST & $17.42^{*}$ & $8.4^{*}$ & $61.25^{* *}$ & 18.17 & $7.61 *$ \\
P alone & 12.07 & 6.9 & 19.52 & 14.20 & 2.08 \\
PSNT & 15.54 & 6.3 & $68.52^{* *}$ & 18.42 & $6.41 *$ \\
PST & $17.37 *$ & $8.2 *$ & $68.25^{* *}$ & 18.51 & $6.52 *$ \\
PCd alone & 12.19 & 7.0 & 18.54 & 14.31 & 2.13 \\
PCdSNT & 16.15 & 6.4 & $71.52^{* *}$ & 16.38 & $7.2 *$ \\
PCdST & $18.63^{*}$ & $8.1 *$ & $70.43^{* *}$ & 17.09 & $6.9 *$ \\
\hline
\end{tabular}

Data are the mean of three replicates tested by Two-way ANOVA analysis following by Tukey's tests. The asterisks * and ${ }^{* *}$ in the same column (nine values) indicate significant difference within treatments at $p<0.05$ and $p<0.01$, respectively. CEC indicates cation exchange capacity; SOM, soil organic matter and P, phosphorus.

\subsection{Effects of Rice Straw on $\mathrm{CaCl}_{2}$ and DTPA-Extractable $\mathrm{Cd}$}

Though $\mathrm{CaCl}_{2}$ and DTPA-extractable $\mathrm{Cd}$ methods used were well-adapted with a recovery rate of $96 \% \pm 3$, the $\mathrm{CaCl}_{2}$-extractable method showed a better correlation between the $\mathrm{Cd}$ plant accumulation and its extraction. This could be related to the increase in $\mathrm{pH}$ and organic matter content, which were reported to dramatically decrease DTPA-extractable heavy metals with their increase in soil [36]. The concentration of $\mathrm{Cd}$ extracted with both $\mathrm{CaCl}_{2}$ and DTPA was significantly low after the addition of rice straw (Figure 3). This can be explained by (i) the involvement of phosphorus concentration, (ii) the immobilization of $\mathrm{Cd}^{2+}$ through the increase in specific absorption, and (iii) the increase of electrostatic interaction and ionic exchange between $\mathrm{Cd}^{2+}$ and the anionic functional group. The addition of rice straw either as modified or unmodified material increased significantly the available phosphorus. This could explain the low concentration of $\mathrm{Cd}$ in both $\mathrm{CaCl}_{2}$ and DTPA extraction. A similar result was found by Cao et al., who showed that phosphorus concentrations in rice straw play an important role in the immobilization of heavy metals, such as $\mathrm{Cd}, \mathrm{Pb}$, and $\mathrm{Zn}$ [37], and reduce the metal translocation from the roots to the shoots by the formation or co-precipitation of insoluble metal phosphates in roots [38]. 


\subsection{Effect of Rice Straw on Phenanthrene Concentration}

PAHs are largely retained on the soil surface through organic partitioning of soil organic matter (SOM) which reduce their bioavailability [39]. The addition of rice straw increased the SOM content (Table 2) and reduced the phenanthrene concentration in soil (Figure 4). This could be attributed to the sorption capacity of SOM content and OC-normalized partitioning coefficient. It is nevertheless important to emphasize that phenanthrene, under precise conditions, can be sorbed by organic matter. However, the sorption coefficient $\mathrm{K}_{\mathrm{oc}}$ may vary with the different types of organic matter, leading to uncertainties in predicting the environmental behavior of phenanthrene [40]. Apart from SOM, soil minerals can significantly contribute to the sorption of PAHs in the soil matrix [41] due to strong non-covalent interactions of their aromatic $\pi$ - donor with sorbed cations on mineral surfaces [42].

\section{5. $\mathrm{Cd}$ and Phenanthrene Interaction}

In the dual treatment, both $\mathrm{Cd}$ and phenanthrene concentrations were significantly reduced in the soil. This suggests an interaction between the two chemicals. The most plausible explanation in this precise case would be the complexation of $\mathrm{Cd}^{2+}$ and phenanthrene, involving cation $\pi$-binding. Several studies have shown that the interaction between PAHs and divalent metal cations is related to cation- $\pi$-interaction [43]. Previously, it was found that, according to the chemical structure of both compounds, phenanthrene and $\mathrm{Cd}^{2+}$ could form a complex due to electrostatic interactions between quadripete benzenes of phenanthrene and positive charges of Cd [44].

\subsection{Soil Microbial and Modified Rice Straw Affected Phenanthrene Concentration}

Though PAHs may undergo adsorption, microbial degradation is the major known mechanism to reduce phenanthrene concentration in soil. However, the extent and rate of degradation depends on several factors including $\mathrm{pH}$, chemical structure, and the microbial population. The addition of modified rice straw increased not only soil microbial community, the abundance of $16 \mathrm{~S}$ rDNA, and the bacterial Shannon index [45], it led to the exposition of some functional groups in the material (Figure 1). The prediction of the functional profile of soil biomes using COGs identified significant changes of individual COGs belonging to carbohydrate metabolism (including bisphenol, benzoate, and ethylbenzene degradation), and signaling pathway (including the cytochrome P450s categories (Figures 5 and 6). This enlightened that the reduction of phenanthrene in the sampling soil was due to degradation or transformation. Figure 8 summarizes the possible mechanism related to how modified rice straw could promote phenanthrene degradation. Indeed, phenanthrene microbial degradation either in aerobic or anaerobic condition required interactions between enzymes and external substrate [46]. Microbial degradation may catabolize and breakdown phenanthrene through biotransformation into less complex metabolites or/and through aerobic/anaerobic mineralization into inorganic minerals; these processes may involve external subtracts such as bicarbonate molecules to activate their metabolism or the hydrogenation of the aromatic ring [18]. After chemical treatment, some functional groups such as $\mathrm{C}-\mathrm{O}, \mathrm{C}-\mathrm{O}-\mathrm{H}, \mathrm{C}-\mathrm{H}$, and $\mathrm{O}-\mathrm{H}$ became more exposed in the material and might be involved in the process of phenanthrene metabolism as external substrates. Thereafter, distinct microorganisms oxidized the carbon molecules through multi-enzyme complexes, such as ring-hydroxylating dioxygenase, that initiated the metabolism of phenanthrene by incorporating an oxygen molecule, resulting in a hydroxylated carbon to alcohol (dihydroxyphenathrene) [47] and the monooxygenase system of cytochrome P450 to catalyze the metabolic activation step of phenanthrene by the diol epoxide pathway, which is hydrolyzed to vicinal dihydrodiol phenanthrene (such as phenanthrene-9,10-dihydrodiol) [16,48]. Subsequently, the alcohol group is oxidized to aldehyde and, finally, to carboxylic acid [49]. Depending on the soil microorganism type, the oxidation of phenanthrene dihydrodiol to simple carbohydrate molecules may be undertaken either by adopting the phtalic acid route as an intermediate or by following the naphthalene route (salicylic acid as an intermediate) before being engaged in the central carbon cycle pathway $[50,51]$. 


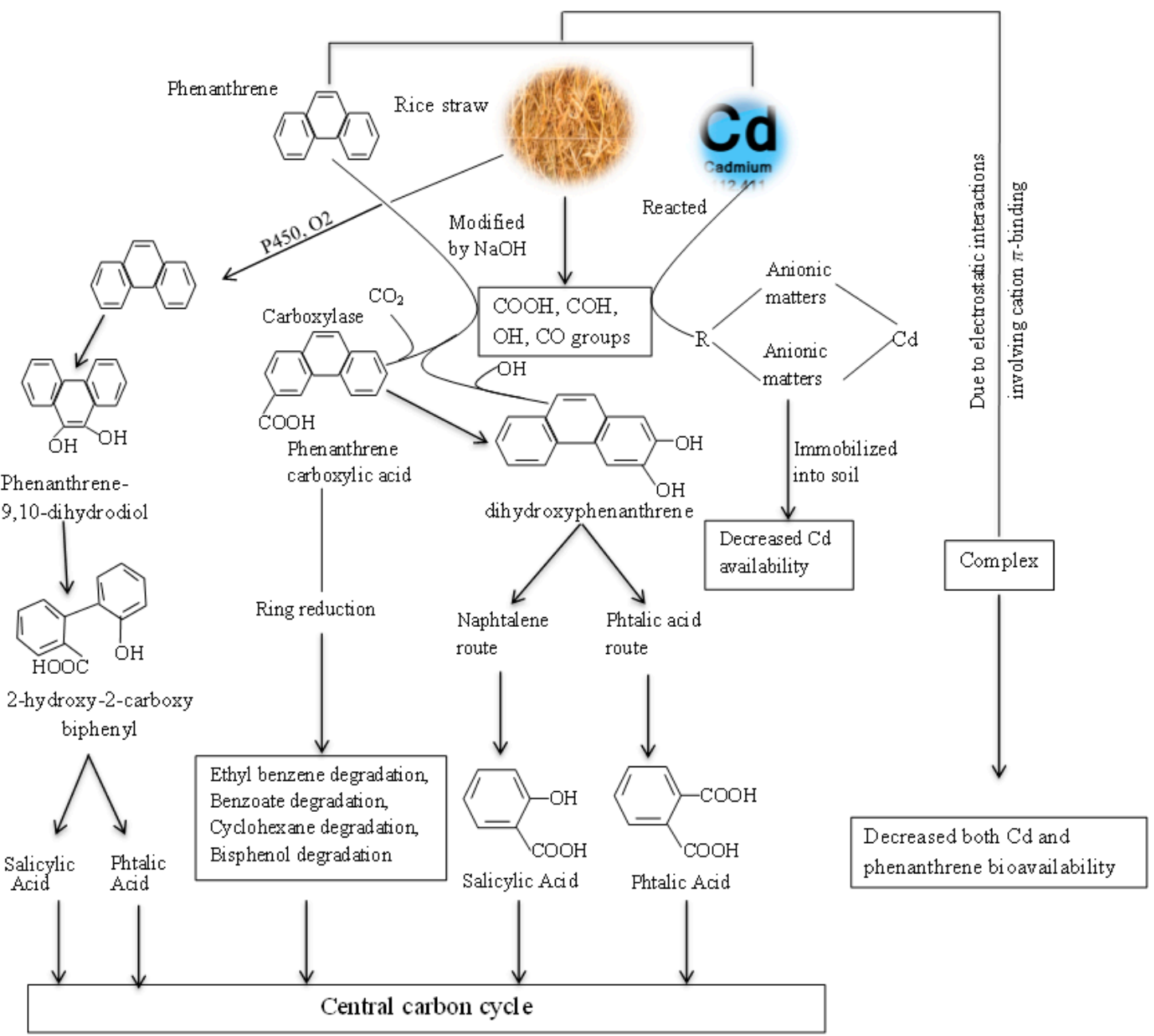

Figure 8. Schema summarizing the different possible mechanisms of rice straw to reduce Cadmium and Phenanthrene accumulation in sunflower plants and promote the degradation of phenanthrene in co-contaminated soil.

\section{Materials and Methods}

\subsection{Soil Properties}

Soil was collected from the test field at Huazhong Agricultural University (HZAU) $\left(30^{\circ} 28^{\prime} 26^{\prime \prime} \mathrm{N}\right.$, $\left.114^{\circ} 20^{\prime} 51^{\prime \prime} \mathrm{E}\right)$, Wuhan, China, transferred to the greenhouse, air-dried, and sieved ( $2 \mathrm{~mm}$ ) before being used. The soil used presented the following properties: $\mathrm{pH}$ (soil: $\mathrm{H}_{2} \mathrm{O}$ 1:2.5) 7.6; organic matter 1.31\%; $\mathrm{NH}_{4} \mathrm{Cl}$ exchangeable $\mathrm{K}, 127.99 \mathrm{mg} / \mathrm{kg}$; total nitrogen $\mathrm{N} 0.17 \%$; Olsen-P of $39.69 \mathrm{mg} / \mathrm{kg}$; CEC 11.47 $\mathrm{cmol}^{+} / \mathrm{kg}$; and Ca, $2288.2 \mathrm{mg} / \mathrm{kg}$

\subsection{Rice Straw Preparation}

Rice straw of Oryza sativa (Taichung Native-1 variety) was collected at the agricultural field of HZAU, transferred to the laboratory, where it was washed three times with distilled water, dried at $60^{\circ} \mathrm{C}$, and crushed with grinder to obtain a fraction with particles size between $0.5-1 \mathrm{~mm}$. The modified rice straw was prepared by adopting the procedure described in [21]. A sufficient quantity of triturated rice straw was dispersed in a $\mathrm{HNO}_{3}$ solution of $1.0 \mathrm{~mol} \mathrm{~L}^{-1}(1: 5, \mathrm{~m}: \mathrm{v})$ and left agitating for $1 \mathrm{~h}$ at the room temperature. The content was after filtered and washed with water to remove the excess of acid in the material. Thereafter, the material was dispersed in a $\mathrm{NaOH}$ solution of $0.75 \mathrm{~mol} \mathrm{~L}^{-1}(1: 10 ; \mathrm{m:v})$ 
and left under agitation for $1 \mathrm{~h}$ at the room temperature. The material once again was filtered, washed exhaustingly with water, and dried at $60{ }^{\circ} \mathrm{C}$.

\subsection{Chemicals Contamination}

Three kg of air-dried soil was placed into ceramic pots for the test experiment. A Cd concentration of $3 \mathrm{mg} \mathrm{kg}^{-1}$ was applied as cadmium chloride $\left(\mathrm{CdCl}_{2}, 98 \%\right.$, purity) solutions. This solution was poured on the soil surface, and the soil matrix was thoroughly mixed and incubated at $20 \pm 1{ }^{\circ} \mathrm{C}$ for three months [52].

Phenanthrene (97\% purity) dissolved in pure acetone (analytically pure) $[53,54]$ was thoroughly mixed with the soil to produce a final concentration of $20 \mathrm{mg} \mathrm{kg}^{-1}$ of phenanthrene. The similar quantity of acetone only was used to prepare the control treatment with clean soil. The fresh contaminated soils were stored in open containers in a fume hood until all of the solvent evaporated [44]. In the chemical mixture treatment, the solution of $20 \mathrm{mg} \mathrm{kg}^{-1}$ of phenanthrene was added in the soil after three months of the incubation of the soil artificially contaminated by $\mathrm{Cd}$ and left for a week before being used for the experiment.

\subsection{Experimental Design}

The experiment had nine treatments with three replicates, regrouped in three groups-including each single chemical contaminant and the mixture treatment. Each group had a control treatment (prepared with soil contaminated either by $\mathrm{Cd}^{2+}$ or phenanthrene only or by both $\mathrm{Cd}^{2+}$ and phenanthrene, respectively) and a treatment with unmodified (SNT) and modified (ST) rice straw for each group (Figure 9). Modified and unmodified straw (5.56 g/kg soil) was applied on the soil surface of the NST and ST treatments; the soil matrix was thoroughly mixed and then moistened with deionized water. This ratio was selected according to Memon previous study, which reported that this is the realistic ratio as a maximum rate of the residue incorporation under field conditions [55].

Five sunflower seedlings (Helianthus annuus $\mathrm{L}$ ) were planted in pots and placed in the greenhouse. During the whole experimental period of 120 days, plants were watered daily and monitored weekly. On the 120 th day, the roots of sunflower were separated from their shoot and cleaned with water from piped supply to remove adhering soils before being washed with deionized water and dried at $60^{\circ} \mathrm{C}$ for 7 days.

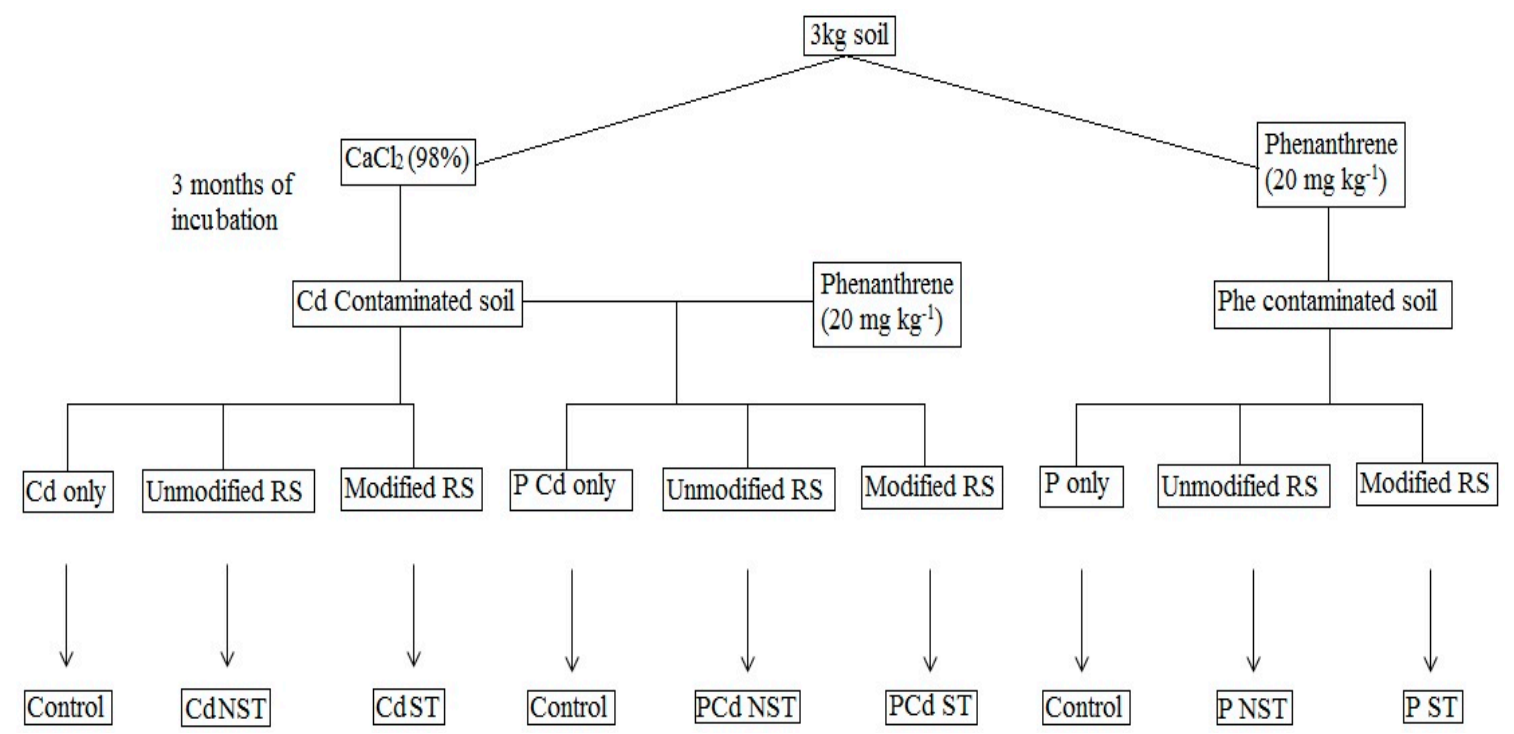

Figure 9. Summary of experimental design with all different treatments. 


\subsection{Analytical Test}

\subsubsection{Total Cadmium Determination}

To conduct a total $\mathrm{Cd}$ in plant tissue analysis, double acid digestion of the sample was applied as described in [56]. Briefly, approximately $0.2 \mathrm{~g}$ of grinded plant sample was digested using $10 \mathrm{~mL}$ of a $\mathrm{HNO}_{3} / \mathrm{HClO}_{4}(4: 1)$ mixture at $200{ }^{\circ} \mathrm{C}$. The digested solution was diluted to $50 \mathrm{~mL}$ using deionized water and filtered before measuring $\mathrm{Cd}$ concentrations in an Atomic Absorption Spectrophotometry (AAS) (Z-2000, HITACHI, Tokyo, Japan). A standard material of plant GBW10015 (GSB-6) approved by general Administration of Quality Supervision, Inspection and Quarantine of the People's Republic of China (AQSIQC) was used for the quality assurance and quality control (QA/QC) of Cd analytical procedure with recovery rate of $93 \pm 7 \%$.

\subsubsection{Extraction of $\mathrm{Cd}$ by $\mathrm{CaCl}_{2}$ and DTPA}

The $\mathrm{Cd}$ concentration of the pore water was measured after extraction with $0.01 \mathrm{M} \mathrm{CaCl}_{2}$ as described in [57]. Heavy metal extracted by DTPA in soil is considered as plant-available [58]. Thus, plant-available $\mathrm{Cd}$ was extracted from the treated soil using DTPA/TEA ( $\mathrm{pH}$ 7.3) as described in [59]. The filtrates were subjected to AAS to determine $\mathrm{Cd}$. The QA/QC for $\mathrm{Cd}$ in soil samples were estimated by determining Cd content in standard materials GBW07405 (GSS-5) purchased from National Central of Standard Materials in China, approved by AQSIQC with a recovery rate of $96 \% \pm 3$.

\subsubsection{Phenanthrene Determination}

The phenanthrene concentration in soil was determined by using the protocol described in our previous study [44]. The accuracy and analysis quality of phenanthrene measurements was estimated by determining phenanthrene content in the certified standard materials NIST1647 Priority Pollutant Polycyclic Aromatic Hydrocarbons in Acetonitril, purchased from Sigma-Aldrich with the recovery rate of $95 \pm 3 \%$.

\subsubsection{Fourier Transform Infrared Spectra of Rice Straw}

FT-IR analysis of rice straw was performed as described in our previous study [23]. In brief, the freeze-dried rice straw sample (10 mg) was mixed with $\mathrm{KBr}(100 \mathrm{mg})$, then ground, homogenized, and pressed to reduce light scatter. Spectra were obtained by scanning the sample from 4000 to $400 \mathrm{~cm}^{-1}$ at $1 \mathrm{~cm}^{-1}$ resolution using Nicolet FTIR iS10 (ThermoFisher Scientific, Co., Ltd, Beijing branch, China)

\subsection{DNA Extraction and Predicted Functional Profile}

After the extraction of total DNA using a DNA isolation kit and the evaluation of quantity and quality by spectrophotometer, the soil bacteria abundance was estimated from qPCR assays targeting $16 \mathrm{~S}$ genes in soil DNA extract. Illumina MiSeq sequencing and universal primers 515F (5'-GTGCCAGCMGCCGCGG-3') and 806R (5'-GGACTACHVGGGTWTCTAAT-3') were used to amplify the $16 \mathrm{~S}$ rRNA V4 region for the analysis of soil microbial community at the Sangon Biotec Institute (Shanghai, China). The detail of the protocol used for the whole process can be found in [60].

To predict functional responses related to the degradation of phenanthrene in soil, PICRUSt [61] was used to generate a functional profile from $16 \mathrm{~S}$ rRNA data. Prior to metagenomes prediction, the OTUs of $16 \mathrm{~S}$ rRNA sequences were normalized by PICRUSt. PICRUSt, clusters of orthologous groups (COGs) [62], and the Kyoto Encyclopedia of Genes and Genomes (KEGG) were used to produce a table of functional genes, which were predicted to be present in the sample and to organize the genes into gene pathways respectively [63]. 


\subsection{Statistical Analysis}

All data were subjected to the ANOVA using SPSS statistical software, One and two-way ANOVA followed by Least significant Difference (LSD) with $95 \%$ confidence level were performed to assess the differences among means and multiple stepwise. A bioinformatics technique, PICRUSt, was used to explore the functional composition of that bacterial community. Network analysis was performed using the CoNet plugin for Cytoscape (http://www.cytoscape.org). Different graphs were drawn using Origin software

\section{Conclusions}

In the present study, it was found that modified rice straw could constitute an excellent bio-sorbent to remove or immobilize $\mathrm{Cd}^{2+}$ in soil, due to the increase of certain functional group including anionic matters groups which can form complexes with $\mathrm{Cd}^{2+}$ exposed on the modified rice straw surfaces. Rice straw also was found to influence soil characteristic which constitute keys factors for the mobility and bioavailability of heavy metals. In addition, the chemical structures of both pollutants may enhance them to interact and form a complex which can diminish the relative significance of the sorption of each pollutant. The modified rice straw, via interaction with soil microorganisms, might reduce phenanthrene concentration in soil. Our study offers clear and strong confirmation that modified rice straw could promote the reduction of heavy metal and the degradation of PAHs in soil. These findings suggest that, by the use of the forsaken natural resources, it is possible to improve the remediation of organic and inorganic pollutants in soil; this will permit a better understanding of soil biological and chemical interaction effects on metal and PAHs remediation technology.

Author Contributions: A.M.E. and C.X.H. conceived and designed the experiment; M.G.M., J.A., and M.I. performed the experiments; M.S.R., and X.Z. contributed to the analysis of data; all others authors edited and revised the manuscript.

Funding: This research was funded by the National Natural Science Foundation of China (Program No. 41271275) and the APC was funded by C.H.

Acknowledgments: This work was supported by the National Natural Science Foundation of China (Program No. 41271275). The authors gratefully acknowledge Agnieszka Rorat from University of Lille, Sciences and Technology, Laboratory of civil Engineering and Geo-Environment, (LGCgE), EA4515, Stephen R. Smith, professor of Bioresource System and head of Environmental and Water Resource Engineering, Department of Civil and Environmental Engineering Imperial College London, South Kensington Campus, London and the laboratory staff members for their remarkable supports.

Conflicts of Interest: The authors declare no conflicts of interest, no other relationships/conditions/circumstances that present potential conflict of interest relationships and have no any patents, whether planned, pending or issued, broadly relevant to the work.

\section{References}

1. Dziubanek, G.; Baranowska, R.; Ćwielag-Drabek, M.; Spychała, A.; Piekut, A.; Rusin, M.; Hajok, I. Cadmium in edible plants from Silesia, Poland, and its implications for health risk in populations. Ecotoxicol. Environ. Saf. 2017, 142, 8-13. [CrossRef] [PubMed]

2. Waigi, M.G.; Kang, F.; Goikavi, C.; Ling, W.; Gao, Y. Phenanthrene biodegradation by sphingomonads and its application in the contaminated soils and sediments: A review. Int. Biodeterior. Biodegrad. 2015, 104, 333-349. [CrossRef]

3. Maigari, A.U.; Maigari, M.U. Microbial metabolism of polycyclic aromatic hydrocarbons (PAHs): A review. Int. J. Sci. Eng. 2015, 6, 1449-1459.

4. Ci, D.; Jiang, D.; Dai, T.; Jing, Q.; Cao, W. Effects of cadmium on plant growth and physiological traits in contrast wheat recombinant inbred lines differing in cadmium tolerance. Chemosphere 2009, 77, 1620-1625. [CrossRef] [PubMed]

5. Wang, J.; Wang, L.; Zhu, L.; Wang, J. Individual and combined effects of enrofloxacin and cadmium on soil microbial biomass and the ammonia-oxidizing functional gene. Sci. Total Environ. 2018, 624, 900-907. [CrossRef] 
6. Wang, C.; Zhou, S.; Song, J.; Wu, S. Human health risks of polycyclic aromatic hydrocarbons in the urban soils of Nanjing, China. Sci. Total Environ. 2018, 612, 750-757. [CrossRef]

7. Maliszewska-Kordybach, B.; Klimkowicz-Pawlas, A.; Smreczak, B.; Janusauskaite, D. Ecotoxic effect of phenanthrene on nitrifying bacteria in soils of different properties. J. Environ. Qual. 2007, 36, 1635-1645. [CrossRef] [PubMed]

8. Gaspar, M.; Cabello, M.; Cazau, M.; Pollero, R. Effect of phenanthrene and Rhodotorula glutinis on arbuscular mycorrhizal fungus colonization of maize roots. Mycorrhiza 2002, 12, 55-59. [CrossRef] [PubMed]

9. Árvay, J.; Tomáš, J.; Hauptvogl, M.; Massányi, P.; Harangozo, l'.; Tóth, T.; Stanovič, R.; Bryndzová, š.; Bumbalová, M. Human exposure to heavy metals and possible public health risks via consumption of wild edible mushrooms from Slovak Paradise National Park, Slovakia. J. Environ. Sci. HealthPart B 2015, 50, 833-843. [CrossRef]

10. Sheoran, A.; Sheoran, V. Heavy metal removal mechanism of acid mine drainage in wetlands: A critical review. Miner. Eng. 2006, 19, 105-116. [CrossRef]

11. Dermont, G.; Bergeron, M.; Mercier, G.; Richer-Laflèche, M. Soil washing for metal removal: A review of physical/chemical technologies and field applications. J. Hazard. Mater. 2008, 152, 1-31. [CrossRef]

12. Kim, T.-Y.; Park, S.-K.; Cho, S.-Y.; Kim, H.-B.; Kang, Y.; Kim, S.-D.; Kim, S.-J. Adsorption of heavy metals by brewery biomass. Korean J. Chem. Eng. 2005, 22, 91-98. [CrossRef]

13. Mahar, A.; Wang, P.; Ali, A.; Awasthi, M.K.; Lahori, A.H.; Wang, Q.; Li, R.; Zhang, Z. Challenges and opportunities in the phytoremediation of heavy metals contaminated soils: A review. Ecotoxicol. Environ. Saf. 2016, 126, 111-121. [CrossRef] [PubMed]

14. Ullah, A.; Heng, S.; Munis, M.F.H.; Fahad, S.; Yang, X. Phytoremediation of heavy metals assisted by plant growth promoting (PGP) bacteria: A review. Environ. Exp. Bot. 2015, 117, 28-40. [CrossRef]

15. Wu, Z.; Zhao, X.; Sun, X.; Tan, Q.; Tang, Y.; Nie, Z.; Hu, C. Xylem transport and gene expression play decisive roles in cadmium accumulation in shoots of two oilseed rape cultivars (Brassica napus). Chemosphere 2015, 119, 1217-1223. [CrossRef] [PubMed]

16. Haritash, A.K.; Kaushik, C.P. Biodegradation aspects of Plocyclic Aromatic Hydrocarbons (PAHs): A review. J. Hazard. Mater. 2009, 169, 1-15. [CrossRef]

17. Davidova, I.A.; Gieg, L.M.; Ducan, K.E.; Sulfita, J.M. Anaerobic phenanthrene mineralization by a carboxylating sulfate-reducing bacterial enrichment. Int. Soc. Microb. Ecol. 2007, 48, 436-442. [CrossRef]

18. Annweiler, E.; Michaelis, W.; Meckenstock, R.U. Identical ring cleavage products during anaerobic degradation of naphthalene, 2-methylnaphthalene, and tetralin indicate a new metabolic pathway. Appl. Environ. Microbiol. 2002, 68, 852-858. [CrossRef]

19. Lu, M.; Zhang, Z.-Z.; Wang, J.-X.; Zhang, M.; Xu, Y.-X.; Wu, X.-J. Interaction of heavy metals and pyrene on their fates in soil and tall fescue (Festuca arundinacea). Environ. Sci. Technol. 2014, 48, 1158-1165. [CrossRef] [PubMed]

20. Liu, S.-H.; Zeng, G.-M.; Niu, Q.-Y.; Liu, Y.; Zhou, L.; Jiang, L.-H.; Tan, X.-f.; Xu, P.; Zhang, C.; Cheng, M. Bioremediation mechanisms of combined pollution of PAHs and heavy metals by bacteria and fungi: A mini review. Bioresour. Technol. 2017, 224, 25-33. [CrossRef] [PubMed]

21. Rocha, C.G.; Zaia, D.A.M.; da Silva Alfaya, R.V.; da Silva Alfaya, A.A. Use of rice straw as biosorbent for removal of $\mathrm{Cu}$ (II), Zn (II), Cd (II) and Hg (II) ions in industrial effluents. J. Hazard. Mater. 2009, 166, 383-388. [CrossRef]

22. Huang, M.; Li, Z.; Huang, B.; Luo, N.; Zhang, Q.; Zhai, X.; Zeng, G. Investigating binding characteristics of cadmium and copper to DOM derived from compost and rice straw using EEM-PARAFAC combined with two-dimensional FTIR correlation analyses. J. Hazard. Mater. 2018, 344, 539-548. [CrossRef]

23. Elyamine, A.; Moussa, M.; Ismael, M.; Wei, J.; Zhao, Y.; Wu, Y.; Hu, C. Earthworms, Rice Straw, and Plant Interactions Change the Organic Connections in Soil and Promote the Decontamination of Cadmium in Soil. Int. J. Environ. Res. Public Health 2018, 15, 2398. [CrossRef]

24. Ding, Y.; Jing, D.; Gong, H.; Zhou, L.; Yang, X. Biosorption of aquatic cadmium (II) by unmodified rice straw. Bioresour. Technol. 2012, 114, 20-25. [CrossRef]

25. Zhao, M.; Zhang, C.; Zeng, G.; Cheng, M.; Liu, Y. A combined biological removal of Cd2+ from aqueous solutions using Phanerochaete chrysosporium and rice straw. Ecotoxicol. Environ. Saf. 2016, 130, 87-92. [CrossRef] 
26. Włóka, D.; Placek, A.; Rorat, A.; Smol, M.; Kacprzak, M. The evaluation of polycyclic aromatic hydrocarbons (PAHs) biodegradation kinetics in soil amended with organic fertilizers and bulking agents. Ecotoxicol. Environ. Saf. 2017, 145, 161-168. [CrossRef]

27. Lin, Z.; Bai, J.; Zhen, Z.; Lao, S.; Li, W.; Wu, Z.; Li, Y.; Spiro, B.; Zhang, D. Enhancing pentachlorophenol degradation by vermicomposting associated bioremediation. Ecol. Eng. 2016, 87, 288-294. [CrossRef]

28. Yuan, Q.; Hernández, M.; Dumont, M.G.; Rui, J.; Scavino, A.F.; Conrad, R. Soil bacterial community mediates the effect of plant material on methanogenic decomposition of soil organic matter. Soil Biol. Biochem. 2018, 116, 99-109. [CrossRef]

29. Zhang, L.; Zhang, S.; Lv, X.; Qiu, Z.; Zhang, Z.; Yan, L. Dissolved organic matter release in overlying water and bacterial community shifts in biofilm during the decomposition of Myriophyllum verticillatum. Sci. Total Environ. 2018, 633, 929-937. [CrossRef]

30. Ding, Z.; Hu, X.; Wan, Y.; Wang, S.; Gao, B. Removal of lead, copper, cadmium, zinc, and nickel from aqueous solutions by alkali-modified biochar: Batch and column tests. J. Ind. Eng. Chem. 2016, 33, 239-245. [CrossRef]

31. Li, J.-H.; Lv, G.-H.; Bai, W.-B.; Liu, Q.; Zhang, Y.-C.; Song, J.-Q. Modification and use of biochar from wheat straw (Triticum aestivum L.) for nitrate and phosphate removal from water. Desalin. Water Treat. 2016, 57, 4681-4693.

32. Lin, Y.; Munroe, P.; Joseph, S.; Henderson, R.; Ziolkowski, A. Water extractable organic carbon in untreated and chemical treated biochars. Chemosphere 2012, 87, 151-157. [CrossRef]

33. Sheng, J.; Ji, D.; Yu, F.; Cui, L.; Zeng, Q.; Ai, N.; Ji, J. Influence of chemical treatment on rice straw pyrolysis by TG-FTIR. Ieri Procedia 2014, 8, 30-34. [CrossRef]

34. McCauley, A.; Jones, C.; Jacobsen, J. Soil pH and organic matter. Nutr. Manag. Modul. 2009, 8, 1-12.

35. Park, J.-H.; Ok, Y.S.; Kim, S.-H.; Cho, J.-S.; Heo, J.-S.; Delaune, R.D.; Seo, D.-C. Competitive adsorption of heavy metals onto sesame straw biochar in aqueous solutions. Chemosphere 2016, 142, 77-83. [CrossRef]

36. Zeng, F.; Ali, S.; Zhang, H.; Ouyang, Y.; Qiu, B.; Wu, F.; Zhang, G. The influence of pH and organic matter content in paddy soil on heavy metal availability and their uptake by rice plants. Environ. Pollut. 2011, 159, 84-91. [CrossRef]

37. Cao, X.; Ma, L.; Liang, Y.; Gao, B.; Harris, W. Simultaneous immobilization of lead and atrazine in contaminated soils using dairy-manure biochar. Environ. Sci. Technol. 2011, 45, 4884-4889. [CrossRef]

38. Zheng, R.-L.; Cai, C.; Liang, J.-H.; Huang, Q.; Chen, Z.; Huang, Y.-Z.; Arp, H.P.H.; Sun, G.-X. The effects of biochars from rice residue on the formation of iron plaque and the accumulation of $\mathrm{Cd}, \mathrm{Zn}, \mathrm{Pb}$, As in rice (Oryza sativa L.) seedlings. Chemosphere 2012, 89, 856-862. [CrossRef]

39. Chen, M.; Xu, P.; Zeng, G.; Yang, C.; Huang, D.; Zhang, J. Bioremediation of soils contaminated with polycyclic aromatic hydrocarbons, petroleum, pesticides, chlorophenols and heavy metals by composting: Applications, microbes and future research needs. Biotechnol. Adv. 2015, 33, 745-755. [CrossRef]

40. Pan, B.; Xing, B.; Tao, S.; Liu, W.; Lin, X.; Xiao, Y.; Dai, H.; Zhang, X.; Zhang, Y.; Yuan, H. Effect of physical forms of soil organic matter on phenanthrene sorption. Chemosphere 2007, 68, 1262-1269. [CrossRef]

41. Zhang, W.; Zheng, J.; Zheng, P.; Tsang, D.C.; Qiu, R. The roles of humic substances in the interactions of phenanthrene and heavy metals on the bentonite surface. J. Soils Sediments 2015, 15, 1463-1472. [CrossRef]

42. Salloum, M.J.; Chefetz, B.; Hatcher, P.G. Phenanthrene sorption by aliphatic-rich natural organic matter. Environ. Sci. Technol. 2002, 36, 1953-1958. [CrossRef]

43. Zhang, W.; Zhuang, L.; Yuan, Y.; Tong, L.; Tsang, D.C. Enhancement of phenanthrene adsorption on a clayey soil and clay minerals by coexisting lead or cadmium. Chemosphere 2011, 83, 302-310. [CrossRef]

44. Elyamine, A.; Afzal, J.; Rana, M.; Imran, M.; Cai, M.; Hu, C. Phenanthrene Mitigates Cadmium Toxicity in Earthworms Eisenia fetida (Epigeic Specie) and Aporrectodea caliginosa (Endogeic Specie) in Soil. Int. J. Environ. Res. Public Health 2018, 15, 2384. [CrossRef]

45. Elyamine, A.; Farid, I.M.; Mahboubat, B.Y.; Nadhurata, A.; Hu, C.X. Impacts of Earthworms and Rice straw on Soil Bacterial Community and Degradation of Phenanthrene. Environ. Sci. Poll. Res.. Manuscript under review.

46. Xenia, M.; Refugio, R. Microorganisms metabolism during bioremediation of oil contaminated soils. J. Bioremed. Biodeg. 2016, 7, 2. 
47. Zhong, Y.; Wang, J.; Carmella, S.G.; Hochalter, J.B.; Rauch, D.; Oliver, A.; Jensen, J.; Hatsukami, D.K.; Upadhyaya, P.; Zimmerman, C. Metabolism of [D10] phenanthrene to tetraols in smokers for potential lung cancer susceptibility assessment: Comparison of oral and inhalation routes of administration. J. Pharmacol. Exp. Ther. 2011, 338, 353-361. [CrossRef]

48. Hecht, S.S.; Carmella, S.G.; Yoder, A.; Chen, M.; Li, Z.-z.; Le, C.; Dayton, R.; Jensen, J.; Hatsukami, D.K. Comparison of polymorphisms in genes involved in polycyclic aromatic hydrocarbon metabolism with urinary phenanthrene metabolite ratios in smokers. Cancer Epidemiol. Prev. Biomark. 2006, 15, 1805-1811. [CrossRef]

49. Szczepaniak, Z.; Czarny, J.; Staninska-Pięta, J.; Lisiecki, P.; Zgoła-Grześkowiak, A.; Cyplik, P.; Chrzanowski, Ł.; Wolko, Ł.; Marecik, R.; Juzwa, W. Influence of soil contamination with PAH on microbial community dynamics and expression level of genes responsible for biodegradation of PAH and production of rhamnolipids. Environ. Sci. Pollut. Res. 2016, 23, 23043-23056. [CrossRef]

50. Andreoni, V.; Gianfreda, L. Bioremediation and monitoring of aromatic-polluted habitats. Appl. Microbiol. Biotechnol. 2007, 76, 287-308. [CrossRef]

51. Deveryshetty, J.; Phale, P.S. Biodegradation of phenanthrene by Pseudomonas sp. strain PPD: Purification and characterization of 1-hydroxy-2-naphthoic acid dioxygenase. Microbiology 2009, 155, 3083-3091. [CrossRef]

52. Li, L.-Z.; Zhou, D.-M.; Wang, P.; Allen, H.E.; Sauvé, S. Predicting Cd partitioning in spiked soils and bioaccumulation in the earthworm Eisenia fetida. Appl. Soil Ecol. 2009, 42, 118-123. [CrossRef]

53. Deng, D.; Lin, X.; Ou, J.; Wang, Z.; Li, S.; Deng, M.; Shu, Y. Efficient chemical oxidation of high levels of soil-sorbed phenanthrene by ultrasound induced, thermally activated persulfate. Chem. Eng. J. 2015, 265, 176-183. [CrossRef]

54. Zhi-Ming, S.; Li, X.; Feng, H. A hierarchic method for studying the distribution of phenanthrene in Eisenia fetida. Pedosphere 2014, 24, 743-752.

55. Memon, M.S.; Guo, J.; Tagar, A.A.; Perveen, N.; Ji, C.; Memon, S.A.; Memon, N. The Effects of Tillage and Straw Incorporation on Soil Organic Carbon Status, Rice Crop Productivity, and Sustainability in the Rice-Wheat Cropping System of Eastern China. Sustainability 2018, 10, 961. [CrossRef]

56. Sakan, S.; Đorđević, D.; Dević, G.; Relić, D.; Anđelković, I.; Đuričić, J. A study of trace element contamination in river sediments in Serbia using microwave-assisted aqua regia digestion and multivariate statistical analysis. Microchem. J. 2011, 99, 492-502. [CrossRef]

57. Houben, D.; Evrard, L.; Sonnet, P. Mobility, bioavailability and pH-dependent leaching of cadmium, zinc and lead in a contaminated soil amended with biochar. Chemosphere 2013, 92, 1450-1457. [CrossRef]

58. Frybarger, M.R. A Baseline Characterization of Trace Elements in Texas Soils. Ph.D. Thesis, Texas A\&M University, College Station, TX, USA, 1998.

59. Lu, K.; Yang, X.; Gielen, G.; Bolan, N.; Ok, Y.S.; Niazi, N.K.; Xu, S.; Yuan, G.; Chen, X.; Zhang, X. Effect of bamboo and rice straw biochars on the mobility and redistribution of heavy metals $(\mathrm{Cd}, \mathrm{Cu}, \mathrm{Pb}$ and $\mathrm{Zn})$ in contaminated soil. J. Environ. Manag. 2017, 186, 285-292. [CrossRef]

60. Cao, J.; Wang, C.; Dou, Z.; Liu, M.; Ji, D. Hyphospheric impacts of earthworms and arbuscular mycorrhizal fungus on soil bacterial community to promote oxytetracycline degradation. J. Hazard. Mater. 2018, 341, 346-354. [CrossRef]

61. Langille, M.G.; Zaneveld, J.; Caporaso, J.G.; McDonald, D.; Knights, D.; Reyes, J.A.; Clemente, J.C.; Burkepile, D.E.; Thurber, R.L.V.; Knight, R. Predictive functional profiling of microbial communities using $16 \mathrm{~S}$ rRNA marker gene sequences. Nat. Biotechnol. 2013, 31, 814. [CrossRef]

62. Tatusov, R.L.; Galperin, M.Y.; Natale, D.A.; Koonin, E.V. The COG database: A tool for genome-scale analysis of protein functions and evolution. Nucleic Acids Res. 2000, 28, 33-36. [CrossRef] [PubMed]

63. Ballou, A.L.; Ali, R.A.; Mendoza, M.A.; Ellis, J.; Hassan, H.M.; Croom, W.; Koci, M.D. Development of the chick microbiome: How early exposure influences future microbial diversity. Front. Vet. Sci. 2016, 3, 2. [CrossRef] [PubMed]

(C) 2019 by the authors. Licensee MDPI, Basel, Switzerland. This article is an open access article distributed under the terms and conditions of the Creative Commons Attribution (CC BY) license (http://creativecommons.org/licenses/by/4.0/). 